\title{
URGENSI GURU DAN KOMPETENSI EDUPRENEUR DALAM DUKUNGAN PENDIDIKAN VOKASIONAL DI SEKOLAH LUAR BIASA
}

\author{
Luqman Hidayat ${ }^{1}$, Viga Saputi ${ }^{2}$ \\ Universitas PGRI Yogyakarta ${ }^{1}$, Universitas Negeri Yogyakarta ${ }^{2}$ \\ e-mail : $\underline{\text { luqman @upy.ac.id }}$
}

\begin{abstract}
Various problems in the world of special education is many of graduates who have not been absorbed in the business world and industrial world. Strengthening the learning process of vocational programs is very important, including strengthening network competence and life skills. An edupreneur can perform the management of vocational skills centers in school according to the needs of the special needs learners so that they can respond to the challenges of the workplace and mistrust of the community to the students with special needs. Management of vocational programs in special schools should be humanistic and take into account the characteristics, needs and types of services appropriate to learners derived from the assessment program to determine the basic capabilities and barriers to enhance the interests and talents of learners.
\end{abstract}

Key words : edupreneur, difable, vocational program

\section{Abstrak}

Berbagai masalah dalam dunia pendidikan khusus adalah banyaknya lulusan yang belum terserap dalam dunia usaha dan dunia industri. Memperkuat proses pembelajaran program vokasional sangat penting dilakukan, termasuk memperkuat kompetensi jaringan kerja dan kecakapan hidup. Seorang edupreneur dapat melakukan manajemen sentra keterampilan vokasional di sekolah sesuai dengan kebutuhan peserta didik kebutuhan khusus sehingga mereka dapat menjawab tantangan dunia kerja dan ketidakpercayaan masyarakat terhadap peserta didik berkebutuhan khusus. Manajemen program vokasional di sekolah khusus harus humanis dan mempertimbangkan karakteristik, kebutuhan dan jenis layanan yang sesuai dengan peserta didik yang berasal dari program assessment untuk mengetahui kemampuan dasar serta hambatan yang dimiliki untuk meningkatkan minat dan bakat peserta didik.

Kata Kunci : edupreneur, anak berkebutuhan khusus, program keterampilan kerja

\section{PENDAHULUAN}

Guru adalah sosok panutan di dalam lingkungan pendidikan bagi para peserta didik dan masyarakat. Guru adalah sosok cerminan bagaimana karakter dan etos kerja yang dimiliki para peserta didiknya. Permasalahan yang dihadapi oleh sekolah luar biasa dan lulusan peserta didik berkebutuhan khusus adalah belum mampu bersaing dengan masyarakat yang heterogen dan belum terserapnya tenaga kerja yang berasal dari golongan difable. Hal ini terjadi karena pembekalan kepada peserta didik kurang maksimal secara spesifik dalam melakukan program pendidikan vokasional. Kedua, sekolah luar biasa belum mampu secara managerial menyiapkan sistem, jejaring Dunia Usaha dan Dunia Industri (DUDI) yang benar-benar dapat menyerap lulusan dari sekolah luar biasa. Dengan kata lain sekolah belum mampu memberi layanan secara baik berdasarkan layanan pendidikan dan layanan khusus secara prima. Ketiga, pembelajaran vokasional pada jenjang SMPLB dan SMPLB atau jenjang menengah selama ini belum menekankan pada kompetensi yang sesuai dengan bakat/minat peserta didik, pemberian keterampilan kerja 
masih dilakukan secara serampangan, terlebih kini masyarakat sedang berlomba dalam pertarungan Masyarakat Ekonomi Asean (MEA) dan Revolusi Industri 4.0 yang semuanya menuntut otomatisasi dan robotisasi dalam berbagai dunia pekerjaan. Ketiga realitas dan permasalahan tersebut, apabila dihadapkan pada harapan layanan guru Pendidikan Khusus yang selama ini dicita-citakan, masih terdapat jurang pemisah yang amat lebar. Melalui kajian ini diharapkan semakin mendekatkan tujuan Pendidikan nasional dengan cita-cita pelayanan pendidikan khusus yang prima.

Berbagai realitas permasalahan keterampilan kecakapan hidup di sekolah khusus harusnya dapat dikelola dengan humanis dengan tujuan membantu peserta didik berkebutuhan khusus dan orangtua siswa yang mempunyai multibackground dalam mengatasi masalah di sekolah khusus, di keluarga dan masyarakat pada umumnya.

Layanan program vokasional dalam Pendidikan Khusus mempunyai spesifikasi tersendiri tiap peserta didik berdasarkan hasil assessment. Guru Pendidikan Khusus sebagai pengelola Pendidikan vokasional di Sekolah Luar Biasa/ Sekolah Khusus harus mempu menjaring bakat-bakat dari para difable yang dalam konsisi sosial masyarakat kita masih menjadi golongan yang termarginalkan. Faktor-faktor yang membedakan penjaringan potensi peserta didik berkebutuan khusus dan regular adalah a) seorang edupreneur harus benar-benar memperhartikan perbedaan individual dan jenis layanan yang harus diterima; 2) seorang edupreneur tidak boleh memukul rata jenis intervensi dan program layanan kecakapan kerja yang akan diberikan kepada peserta didik; 3) seorang edupreneur harus mengikuti budaya dan tantangan di masyarakat, sehingga mampu membaca peluang, kebutuhan spesifikasi tenaga kera di masyarakat dengan tetap mempertimbangkan aspek sumber daya alam dan potensi daerah yang dimiliki dengan tetap mempertimbangkan potensi peserta didik berkebutuhan khusus. Dengan adanya program sekolah yang baik dan terencana untuk meningkatkan kapasitas peserta didik dalam kecakapan hidup, seorang guru edupreneur juga harus mempunyai kecakapan mengelola sumberdaya manusia di lingkungan pendidikan. Semakin kompleks lintas pendidikan keterampilan kerja di sekolah, maka akan semakin banyak mendukung keberhasilan peserta didik berkebutuhan khusus di masa yang akan datang.

Seorang edupreneur atau teacherpreneur yang bekerja di sekolah berusaha membantu peserta didik berkebutuhan khusus yang sesuai dengan metode yang cocok sesuai dengan karakteristik dan kebutuhan peserta didik agar ada hubungan timbal-balik dengan guru, peserta didik, program vokasional serta dunia usaha dan industri sehingga setiap peserta didik berkebutuhan khusus lebih memaknai hidup dan memperoleh tujuan hidup yang lebih realistis, sehingga peserta didik dapat menjadi masyarakat yang berbahagia dan lebih produktif.

\section{PEMBAHASAN}

\section{Paradigma Guru Pendidikan Khusus}

Undang-undang RI No 20 tahun 2003 tentang Sistem Pendidikan Nasional Pasal 1, mengenai ketentuan umum butir 6, menyatakan bahwa pendidik adalah tenaga kependidikan yang berkualifikasi sebagai guru, dosen, konselor, pamong belajar, widyaiswara, tutor, instruktur, fasilitator, dan sebutan lain yang sesuai dengan kekhususannya, serta berpartisipasi dalam menyelenggarakan pendidikan. Lebih rinci dijelaskan dalam Undang-undang RI No 14 Tahun 2005 tentang guru dan dosen pada bab I pasal 1, menyatakan bahwa guru adalah pendidik profesional dengan tugas utama mendidik, mengajar, membimbing, mengarahkan, melatih, menilai, dan mengevaluasi peserta didik pada pendidikan 
anak usia dini jalur pendidikan formal, pendidikan dasar, dan pendidikan menengah (Shabir, 2015: 221). Zahara Idris dan Lisma Jamal (dalam Idris 2008: 49) mendefinisikan guru merupakan orang dewasa yang bertanggung jawab memberikan bimbingan kepada peserta didik dalam hal perkembangan jasmani dan ruhaniah untuk mencapai tingkat kedewasaan, memenuhi tugasnya sebagai makhluk Tuhan, makhluk individu yang mandiri, dan makhluk sosial. Berdasarkan pernyataan ahli di atas dapat dikaji bahwa guru merupakan seseorang pendidik/pengajar yang bertugas memberikan bimbingan, pelatihan, pengajaran, dan evaluasi bagi peserta didik baik secara jasmani maupun ruhaniah dalam lingkup pendidikan formal, dasar, dan menengah demi mencapai tujuan pendidikan. Guru dalam peranannya di bidang pendidikan sangatlah vital bagi perkembangan peserta didik. Tidak hanya membekali dengan ilmu maupun keterampilan tetapi seorang guru juga harus sungguh-sungguh mempersiapkan peserta didik dalam mendorong dan momotivasi siswa untuk terjun ke masyarakat pasca sekolah. Guru sebagai seorang pendidik harus mampu mengenali karakteristik maupun potensi peserta didik yang dapat dikembangkan sebagai bekal tercapainya kemandirian. Berbekal kompetensi yang dimiliki guru maka dapat menunjang kebutuhan peserta didik demi mencapai tujuan pendidikan.

\section{Kompetensi Edupreneur}

Menurut Harris (2000), kompetensi adalah "...are underlying bodies of knowladge, abilities, experiences, and other requirement necessary to succesfully perform the job". Kompetensi meliputi sikap, motivasi, nilai serta tingkah laku yang diberikan untuk melaksanakan pekerjaan. Selain itu, Direktorat Pembinaan SLB (2008:7) menjelaskan kompetensi adalah seperangkat sikap, pengetahuan, dan keterampilan beserta nilai-nilai yang harus dimiliki, dikuasai, dan dihayati oleh peserta didik di bidang tertentu. Setiawan dan Sitorus (2017: 124) menyatakan bahwa kompetensi merupakan perpaduan dari penguasaan pengetahuan, keterampilan, nilai, dan sikap yang direfleksikan melaui kebiasaan berpikir dan bertindak dalam kehidupan sehari-hari. Oleh karena itu dapat dikaji bahwa kompetensi adalah sikap, pengetahuan, motivasi, keterampilan, dan nilai-nilai yang melekat pada seseorang yang direfleksikan melalui kebiasaan berpikir dan bertindak untuk melaksanakan suatu pekerjaan. Sementara itu, EduPreneur berasal dari kata education (pendidikan) dan entrepreneur (wirausahawan) yang berarti pengusaha edukasi atau pengusaha pendidikan. Reena Agrawal (2013: 5) menjelaskan bahwa dalam sektor pendidikan terdapat istilah "EduPreneur" yang merupakan sebutan dari lembaga pendidikan yang mengembangkan usaha kreatif dan inovatif dalam sektor pendidikan. Selain itu, edupreneur menurut Charles W. Lavaroni, M.S. \& Donald E. Leisey (2011) adalah seseorang yang telah berprofesi sebagai pendidik bahkan sebelum mengorganisir sebuah bisnis yang berkaitan dengan pendidikan dan telah menginvestasikan waktu, energi, dan modal untuk menciptakan, mengembangkan, dan memasarkan program, produk, layanan, atau teknologi untuk meningkatkan kuantitas dan kualitas pembelajaran. Maka dari itu edupreneur dimaknai sebagai seseorang yang melakukan usaha kreatif dan inovatif dalam mengembangkan program, produk, layanan, atau teknologi dalam sektor pendidikan. Sangat jelas bahwa kompetensi edupreneur merupakan seperangkat sikap, pengetahuan, motivasi, keterampilan, dan nilai-nilai yang melekat pada diri seseorang dalam lembaga pendidikan yang diwujudkan melalui cara berpikir dan bersikap dengan mengembangkan usaha kreatif dan inovatif dalam menciptakan, mengembangkan, dan memasarkan berbagai program, produk, 
layanan atau teknologi yang bermanfaat bagi mutu pendidikan.

\section{Pendidikan Vokasional bagi Anak Berkebutuhan Khusus}

Pendidikan vokasional berorientasi pada kesiapan kerja lulusannya. Menurut Kamus Besar Bahasa Indonesia (KBBI, 2002: 1263) vokasional diartikan sebagai yang bersangkutan dengan (sekolah) kejuruan atau bersangkutan dengan bimbingan kejuruan. Hal ini berarti vokasional berkaitan dengan keterampilan khusus yang dimiliki seseorang sebagai bekal untuk mencari nafkah dan sumber penghidupan.

Pendidikan vokasional tidak lepas dari adanya program yang memuat suatu pembelajaran dan dapat diterapkan dengan berbagai metode sesuai kondisi siswa. Pembelajaran keterampilan vokasional diarahkan agar peserta didik dapat mengembangkan kecakapan hidup (life skill) yang meliputi keterampilan personal, sosial, pra vokasional, vokasional, dan akademik (Hasan Rochjadi dan Tia Nurmeliawati, 2017: 66). Undang-Undang No 22 Tahun 2006 tentang Standar Isi Pendidikan Pembelajaran Keterampilan pravokasional di SMPLB dan vokasional di SMALB bertujuan agar peserta didik memiliki kemampuan :

1. Mampu mengembangkan pengetahuan dan keterampilan dalam mengembangkan berbagai produk kerajinan maupun teknologi yang bermanfaat.

2. Memiliki rasa estetika, apresiasi terhadap produk kerajinan, produk teknologi, dan artefak dari berbagai wilayah di Nusantara dan dunia.

3. Mampu mengidentifikasi potensi daerah setempat yang dapat dikembangkan melalui kegiatan kerajinan dan pemanfaatan teknologi sederhana.

4. Bersikap profesional dan kewirausahaan.
Andriyanti (Hasan Rochjadi dan Tia Nurmeliawati, 2017: 67) menspesifikasikan tujuan pembelajaran keterampilan vokasional bagi anak berkebutuhan khusus yaitu:

1. Mengembangkan pengetahuan melalui penelaahan jenis, bentuk, sifat, penggunaan dan kegunaan alat, bahan, proses, dan teknik membuat berbagai produk kerajinan dan produk teknologi yang berguna bagi kehidupan, termasuk pengetahuan dalam konteks budaya dari bendabenda tersebut.

2. Mengembangkan kepekaan rasa estetik, rasa menghargai terhadap produk hasil kerajinan dan teknologi masa kini serta artefak masa lampau dari berbagai wilayah Nusantara maupun dunia.

3. Mengembangkan keterampilan untuk menghasilkan produk kerajinan dan produk teknologi serta industri sederhana yang berguna bagi kehidupan manusia dengan menerapkan ilmu pengetahuan yang diperolehnya.

4. Menanamkan apresiasi tatanan kehidupan dunia termasuk budaya bangsanya sehingga menumbuhkan kecintaan budaya berkarya yang bercirikan Indonesia.

5. Mengembangkan kepekaan kreatif melalui berbagai kegiatan penciptaan benda-benda produk kerajinan dan teknologi dengan menggunakan bahan alam maupun industri.

6. Mengembangkan sikap toleransi, demokrasi, beradab, mandiri, serta mampu hidup rukun dalam masyarakat yang majemuk.

7. Menumbuhkembangkan sikap profesional, kooperatif, toleransi, kepemimpinan (leadership), kekaryaan (employmenship), dan kewirausahaan (entrepreneurship). 
Hal ini menjadikan pendidikan vokasional sebagai landasan bagi peserta didik berkebutuhan khusus agar memiliki dan mampu mengembangkan pengetahuan, keterampilan, rasa estetika, rasa apresiasi terhadap suatu produk. Peserta didik juga harus mampu melihat peluang di lingkungan sekitar untuk pengembangan kewirausahaannya. Seiring dengan pengembangan tersebut, peserta didik berkebutuhan khusus terasah kepekaan kreativitasnya, semangat profesional, dan kepemimpinan. Berbekal kemampuan vokasional yang dimiliki diharapkan peserta didik dapat menjadi wirausahawan guna mencapai kehidupan yang mandiri dan sejahtera.

Untuk menjawab tantangan yang dihadapi peserta didik berkebutuhan khusus kedepan ketika sudah lulus dari jenjang Pendidikan adalah daya saing dengan masyarakat yang begitu heterogen. Edupreuner harus mampu membaca dan menciptakan peluang bisnis yang dapat diakses oleh peserta didik berkebutuhan khusus. Di Sentra PK-PLK bagi peserta didik berkebutuhan khusus kini telah mengedepankan keterampilan kerja/vokasional sehingga seorang edupreneur/teacherpreneur harus menjadi motivator dan fasilitator untuk mengarahkan peserta didik pada keterampilan kerja sesuai dengan bakat/minatnya. Selain itu seorang edutpreneur harus menciptakan gairah peserta didik berkebutuhan khusus agar mampu mengembangkan potensi yang dimilikinya. Dalam Peraturan Dirjen Pendidikan Dasar dan Menengah Nomor:10/D/KR/2017 Tentang Struktur Kurikulum, Kompetensi Inti-Kompetensi Dasar, dan Pedoman Implemntasi Kurikulum 2013 Pendidikan Khusus memberikan porsi 18 JP untuk SMPLB dan 24 JP sd 26 JP untuk SMALB khusus untuk program keterampilan pilihan, sehingga seorang edupreuner harus bisa memanagement kegiatan pembelajaran vokasional di sekolah khusus. Setelah peserta didik matang dalam program keterampilan pilihan di sekolah, Edupreuner harus mengarahkan pada kegiatan magang sekurang-kurangnya 1 bulan pada kelas XI, sehingga seorang edupreuner harus mempunyai jejaring dunia usaha dan dunia industri (DUDI) yang baik.

Seorang Guru Sekolah Luar Biasa sebagai pemeran edupreneur merupakan pemegang keberhasilan edupreneurship dalam setting sekolah, tidak boleh mengabaikan potensi peserta didik yang beraneka ragam berdasarkan kebutuhan dan layanannya. Keberagaman potensi tersebut selayaknya menjadi acuan guru dalam menetapkan arah pendidikan vokasional bagi peserta didik. Hasil yang diperoleh menjadikan siswa mampu mencapai tujuan pendidikan vokasional yang diharapkan.

\section{SIMPULAN}

Berdasarkan hasil kajian di aas maka dapat diambil kesimpulan bahwa : (1) kompetensi edupreneur sangat diperlukan guru atau calon guru Pendidikan khusus/Pendidikan Luar Biasa; Pembentukan peserta didik berkebutuhan khusus dalam kompetensi kecakapan hidup perlu memperhatikan jenis kebutuhan dan layanan yang sesuai dengan tiap individu anak berkebutuhan khusus. (3) Guru harus mampu memodifikasi kurikulum sesuai dengan kebutuhan dan potensi yang dimiliki peserta didik, sekolah dan masyarakat sebagai tempat kembalinya peserta didik berkebutuhan khusus.

Saran yang dapat diberikan adalah untuk hasil kajian pustaka ini dapat dikembangkan suatu penelitian dan kajian lebih lanjut dari implementasi guru di sekolah luar biasa / sekolah khusus dalam program vokasinal di sekolah luar biasa, dan semakin memantapkan arah Pendidikan Nasional tanpa diskriminatif. 


\section{DAFTAR PUSTAKA}

Agrawal, R. (2013). How to identify and Select a Business Opportunity and Then Implement the Business Idea? A Case on Edupreneurship in India. Journal of Business Studies Quarterly, 2013, Volume 4, Number 4.

Charles W. Lavaroni, M.S. \& Donald E. Leisey. (2011). The Edupreneur. http://www.edentrepreneurs.org/edupreneur.php

Setiawan, D. \& Sitorus, J. (2017). Urgensi Tuntutan Profesionalisme dan Harapan menjadi Guru Berkarakter (Studi Kasus: Sekolah Dasar dan Sekolah Menengah Pertama di Kabupaten Batubara). FIS Universitas Negeri Medan dan Balitbang Sumatera Utara. Jurnal Cakrawala Pendidikan, Februari 2017, Th. XXXVI, No. 1

Direktorat Pembinaan SLB. (2008). Pedoman Kompetensi Keterampilan Siswa "HANTARAN" Tingkat Dasar SLB-B, C (Ringan), D, E. Jakarta.

Harris, M. (2000). Human Resource Management. Illinois : Dryden Press.

Rochjadi, H. Nurmeliawati, T. (2017). Modul Pengembangan Keprofesian Berkelanjutan (Terintegrasi Penguatan Pendidikan Karakter) Bidang PLB Tuna Grahita Kelompok Kompetensi H (Pedagogik : Penilaian Pembelajaran bagi Anak Tunagrahita; Profesional: Pengembangan Vokasional Sederhana dan Kemitraan). Jakarta: Kemendikbud.

Idris, Muhamad. (2008). Kiat Menjadi Guru Profesional. Cet. I; Yogyakarta: Ar-Ruzz Media. M. Shabir. U. Kedudukan Guru sebagai Pendidik: (Tugas dan Tanggung Jawab, Hak dan Kewajiban, dan Kompetensi Guru). Fakultas Tarbiyah dan Keguruan UIN Alauddin Makassar. Auladuna, Vol. 2222 No. 2 Desember 2015: 221-232.

Tim Redaksi KBBI PB. (2008). Kamus Besar Bahasa Indonesia (Edisi Keempat). Jakarta: Pusat Bahasa Departemen Pendidikan Nasional

Undang Undang Nomor 20 tahun 2003 tentang Sistem Pendidikan Nasional.

Undang-undang No 22 Tahun 2006 tentang Standar Isi Pendidikan Pembelajaran Keterampilan pravokasional di SMPLB dan vokasional di SMALB

Undang-undang Republik Indonesia No 14 Tahun 2005 tentang Guru dan Dosen. 